\title{
Expression of the Mouse Corticotropin-releasing Hormone Gene In Vivo and Targeted Inactivation in Embryonic Stem Cells
}

\author{
Louis J. Muglia, " Nancy A. Jenkins, ${ }^{\star}$ Debra J. Gilbert, ${ }^{*}$ Neal G. Copeland, ${ }^{\star}$ and Joseph A. Majzoub * \\ ${ }^{*}$ Division of Endocrinology, Children’s Hospital, Boston, Massachusetts 02115; and ${ }^{\ddagger}$ Mammalian Genetics Laboratory, ABL-Basic \\ Research Program, National Cancer Institute-Frederick Cancer Research and Development Center, Frederick, Maryland 21702
}

\begin{abstract}
Corticotropin-releasing hormone (CRH), one of the primary regulators of the hypothalamic-pituitary-adrenal (HPA) axis, exhibits abnormal regulation in pathologic states such as depression and anorexia nervosa. Analysis of the role of $\mathrm{CRH}$ in regulation of the HPA axis would be facilitated by the creation of animal models in which CRH gene structure and function could be manipulated. We have determined the DNA sequence of the mouse CRH gene. Using a highly sensitive reverse transcription-polymerase chain reaction method, we have found expression of CRH mRNA in adrenal, ovary, testis, gut, heart, anterior pituitary, lung, and spleen, in addition to cerebral cortex and hypothalamus. Within the spleen, CRH mRNA is localized specifically to T-lymphocytes. We mapped the chromosomal location of mouse CRH via interspecific mouse backcrosses to chromosome 3 , which is not the site of any naturally occurring mutations consistent with CRH deficiency. Because of this, we inactivated a CRH allele in mouse embryonic stem (ES) cells by homologous recombination with a mutant mouse CRH gene lacking the entire coding region of preproCRH. Mice chimeric for each of two ES clones with an inactivated CRH allele are being used to generate animals with complete CRH deficiency. (J. Clin. Invest. 1994. 2066-2072.) Key words: interspecific backcross analysis - chromosome $\cdot$ embryonic stem cells - fluorescence-activated cell sorting • gene structure
\end{abstract}

\section{Introduction}

Corticotropin-releasing hormone $(\mathrm{CRH})^{1}$ has a central role in the regulation of the hypothalamic-pituitary-adrenal (HPA) axis, and thus in the mammalian response to stress (1). Outside of the paraventricular nucleus of the hypothalamus, CRH and its receptor are found throughout the cerebral cortex (2, $3)$. CRH peptide or mRNA has also been found in rat testis (3, $4,5)$, ovary (6), and adrenal medulla (7), human lung (8) and placenta (9), and rodent $(10,11)$ and human (12) immune cells. Although the function of CRH synthesized in extra-hypothalamic sites is unknown, $\mathrm{CRH}$ may act within the cerebral

Address all correspondence to Louis J. Muglia, M.D., Ph.D., Division of Endocrinology, Children's Hospital, 300 Longwood Ave., Boston, MA 02115.

Received for publication 2 November 1993 and in revised form 31 December 1993.

1. Abbreviations used in this paper: AVP, arginine vasopressin; CRH, corticotropin-releasing hormone; ES, embryonic system; HPA, hypothalamic-pituitary-adrenal.

The Journal of Clinical Investigation, Inc.

Volume 93, May 1994, 2066-2072 cortex as a neuromodulator (13) and mediate some forms of stress-related behavior (14), and within the immune system it may either suppress (15) or stimulate (16) immune function.

When initially characterized by Vale et al. (17) in 1981, CRH was thought to be the major regulator of pituitary ACTH production. More recently, however, the relative importance of CRH in comparison with other regulators of the HPA axis, such as arginine vasopressin (AVP) and catecholamines has become less clear. Classical physiologic studies in rats using antagonists of CRH, AVP, or adrenergic agents (18), or neutralizing antibodies to CRH or AVP (19), to define the relative contribution of CRH to the HPA response to stress have yielded valuable, but often conflicting, results. In humans, neither CRH nor AVP alone can completely account for ACTH release in various stressful settings $(20,21,22)$, and neither the relative importance of endogenous $C R H$ versus AVP release nor a causal relationship between such release and ACTH secretion during stress has been firmly established. Molecular genetic analysis of CRH function in a whole animal system in which mutations of the $\mathrm{CRH}$ gene can be introduced would be a powerful means of assessing both the contribution of $\mathrm{CRH}$ to the regulation of the HPA axis, as well as the role of $\mathrm{CRH}$ synthesized in extra-hypothalamic sites. With the advent of transgenic mouse technologies, and, specifically, targeted gene inactivation ("knockouts") in embryonic stem cells, a method of directly assessing the function of the CRH gene in vivo is now possible (23). A necessary prerequisite for analyzing the phenotypes produced in mice carrying inactive or otherwise altered CRH transgenes is knowledge of the normal pattern of $\mathrm{CRH}$ gene expression and regulation. In this paper, we extend the structural characterization of the mouse CRH gene. Since marked species differences in extra-hypothalamic sites of $\mathrm{CRH}$ expression have been observed, we have also used a very sensitive reverse transcription polymerase chain reaction (PCR) assay in an effort to define the distribution of CRH mRNA expression in the mouse, and to more precisely localize the cell type responsible for CRH synthesis in the immune system. We have also defined the chromosomal location of the mouse CRH gene in a search for naturally occurring mutants. Finding none, we have undertaken the generation of a CRH-deficient mouse by inactivating the $\mathrm{CRH}$ gene in mouse embryonic stem (ES) cells and using these cells to construct mice highly chimeric for the inactivated CRH allele.

\section{Methods}

Isolation of the mouse CRH gene. A Balb/c genomic library (Clontech, Palo Alto, CA) in lambda EMBL3 SP6/T7 was screened with a random-primed ${ }^{32} \mathrm{P}$-labeled 700-bp Rsal fragment from the coding region of the rat CRH cDNA (24). 240,000 phage plaques grown in E. coli strain LE392 were transferred to nitrocellulose filters in duplicate, hybridized at $65^{\circ} \mathrm{C}$ in $5 \times \operatorname{SSC}(0.75 \mathrm{M} \mathrm{NaCl}, 0.075 \mathrm{M}$ sodium citrate $)$, $5 \times$ Denhardt's solution $(0.1 \%$ polyvinylpyrrolidine, $0.1 \%$ bovine 
serum albumin, $0.1 \%$ Ficoll, type 400 ), $0.5 \%$ sodium dodecyl sulfate (SDS), $100 \mu \mathrm{g} / \mathrm{ml}$ sonicated salmon sperm DNA, and washed at a final stringency of $0.1 \times \mathrm{SSC}, 0.1 \% \mathrm{SDS}$ at $65^{\circ} \mathrm{C}$. The phage containing the mouse CRH gene, $\lambda E 3 g m C R H$, was plated to homogeneity before DNA purification as described in Sambrook et al. (25).

Southern blot analysis. Agarose gel electrophoresis and transfer to Gene Screen (Dupont NEN, Boston, MA) were done according to standard protocols (25). $3.5 \mu \mathrm{g}$ of mouse genomic DNA or $100 \mathrm{pg}$ of $\lambda E 3 g m C R H$ were cut with EcoRI, PstI, or EcoRI plus PstI, and subjected to electrophoresis through $0.8 \%$ agarose. Filters were probed with a random-primed labeled 970-bp Sal I-BamHI fragment from the mouse CRH clone.

DNA sequence analysis. All sequencing reactions were done using the dideoxynucleotide chain termination method (26), T7 DNA polymerase (Sequenase; United States Biochemical Corporation, Cleveland, $\mathrm{OH})$, and ${ }^{35} \mathrm{~S}-\alpha$-dATP. Guanine-cytosine rich areas were sequenced with reaction mixes containing either dGTP or dITP. Reactions were run on $6 \%$ polyacrylamide, $8 \mathrm{M}$ urea gels, and exposed to Kodak XAR 5 film (Eastman Kodak Co., Rochester, NY). Nucleotide positions were numbered with the transcriptional start site, determined by comparison with that of the human gene (27), designated as +1 .

Interspecific mouse backcross mapping. Interspecific backcross progeny were generated by mating (C57BL/6J $\times$ Mus spretus $) \mathrm{F}_{1}$ females and $\mathrm{C} 57 \mathrm{BL} / 6 \mathrm{~J}$ males as described (28). This interspecific backcross mapping panel has been typed for over 1,100 loci that are well distributed among all the autosomes as well as the $\mathrm{X}$ chromosome. A total of $205 \mathrm{~N}_{2}$ backcross mice were used to map the Crh locus (see Results for details). DNA isolation, restriction enzyme digestion, agarose gel electrophoresis, Southern blot transfer, and hybridization were performed essentially as described (29). All blots were prepared with Zetabind nylon membrane (AMF-Cuno, Levalloit-Peret, France). The probe used was the 970-bp SalI-BamHI mouse CRH genomic DNA fragment labeled with ${ }^{32} \mathrm{P}-\alpha-\mathrm{dCTP}$ by nick translation (Boehringer Mannheim, Indianapolis, IN). A 15.0-kb fragment was detected in C57BL/6J DNA digested with HindIII and a 10.5-kb fragment was detected in $M$. spretus DNA digested with HindIII. The presence or absence of the 10.5-kb M. spretus-specific HindIII restriction fragment length polymorphism was followed in backcross mice.

A description of the probes and RFLPs for the loci linked to $\mathrm{Crh}$ including interleukin-7 (Il-7), glucose transporter-2 (Glut-2), and fibroblast growth factor, beta subunit $(F g f b)$ has been reported previously $(30,31,32)$. Recombination distances were calculated as described (33) using the computer program SPRETUS MADNESS. Gene order was determined by minimizing the number of recombination events required to explain the allele distribution patterns.

Messenger RNA analysis using reverse transcription-polymerase chain reaction. Total cellular RNA was isolated from tissues of adult CD1 mice by the guanidinium thiocyanate-cesium chloride method (34) $.2 \mu \mathrm{g}$ of RNA were used as a template for CDNA synthesis initiated from random hexamer primers in a reaction volume of $20 \mu$ l. Polymerase chain reaction (PCR) amplification of this CDNA was performed using a sense strand primer from the $3^{\prime}$ end of mouse $\mathrm{CRH}$ exon 1 ( $5^{\prime}$ GCATCCTGAGAGAAGTCCCTCTG $3^{\prime}$ ) and a reverse strand primer from the coding region of rat $\mathrm{CRH}$ exon 2 which differs by only one internal base from the mouse (5' GCCCTGGCCATTTCCAAGAC $\left.3^{\prime}\right)$. Contaminating genomic DNA produces a PCR product of 1,267 bp, whereas CRH mRNA produces a PCR product of $585 \mathrm{bp}$. Initial sample denaturation was $94^{\circ} \mathrm{C}$ for $3 \mathrm{~min}$, followed by 25 (general survey) or 35 ( spleen fractionation) cycles of $96^{\circ} \mathrm{C}$ for $30 \mathrm{~s}, 55^{\circ} \mathrm{C}$ for $30 \mathrm{~s}$, and $72^{\circ} \mathrm{C}$ for $3 \mathrm{~min}$. Reactions were completed with an additional 3-min extension at $72^{\circ} \mathrm{C}$. One fifth of the PCR reaction product was subjected to electrophoresis through $1.3 \%$ agarose, transferred to nitrocellulose, and hybridized to a random-primed ${ }^{32} \mathrm{P}$-labeled 320-bp PstIRsal fragment from exon 2 of the mouse CRH gene. Amplification of interleukin- $1 \alpha$ cDNA was performed as described in Murray et al. (35).

Splenocyte fractionation. Spleens from six CD1 mice were minced with fine scissors in $9 \mathrm{ml}$ of Hank's buffered salt solution (HBSS) containing $20 \mathrm{mM}$ Hepes and $0.3 \%$ bovine serum albumin, $\mathrm{pH}$ 7.3. Small tissue fragments were additionally dispersed by teasing with fine forceps. The cell suspension was layered over Histopaque 1083 (Sigma Chemical Co., St. Louis, MO), and centrifuged for $20 \mathrm{~min}$ at $1,200 \mathrm{~g}$. The leukocyte band at the Hank's-Histopaque interface was isolated and washed three times in HBSS, then resuspended in $10 \mathrm{ml}$ of RPMI medium (GIBCO BRL, Life Technologies, Inc., Gaithersburg, MD) with $10 \%$ fetal bovine serum (JRH Biosciences, Lenexa, KS). This suspension was plated on a $10-\mathrm{cm}$ tissue culture dish for $1.5 \mathrm{~h}$ to allow macrophages to adhere. The non-adherent cells were removed and centrifuged. Pellets were resuspended in $1.5 \mathrm{ml}$ of RPMI with $10 \%$ fetal bovine serum. These cells were incubated with a mixture of fluorescein isothiocyanate-conjugated anti-CD45 and phycoerythrin-conjugated anti-Thy 1.2 monoclonal antibodies (Pharmingen, San Diego, CA) on ice for $30 \mathrm{~min}$, washed in RPMI with $10 \%$ fetal bovine serum three times, and subjected to fluorescence-activated cell sorting (36). B-cell and T-cell populations were processed separately for RNA by the guanidium thiocyanate-cesium chloride method, as was the adherent population. RNA was subjected to reverse-transcription PCR as described above.

Inactivation of CRH allele in ES cells. Wild-type and targeted mutants in the D3 line (37) of ES cells, kindly provided by R. Hynes (Massachusetts Institute of Technology, Cambridge, MA) were cultured as described by Robertson (38), with leukemia inhibitory factor added to the media at $10^{3} \mathrm{U} / \mathrm{ml}$. The cells were grown on primary mouse embryonic fibroblasts harvested at $14 \mathrm{~d}$ gestation, mitotically inactivated with 3,000 rads of gamma-irradiation.

We used our mouse CRH genomic clone to generate a construct for homologous recombination. The vector pPNT (39), kindly provided by R. Mulligan (Massachusetts Institute of Technology), containing the neomycin resistance and herpes thymidine kinase genes driven by the mouse phosphoglycerate kinase-1 promoter, was used as a backbone for insertion of an EcoRI-Sall 5-kb mouse CRH 5' flanking sequence extending from $-5,000$ to -50 bp (first cloned into pBluescript) (Stratagene, La Jolla, CA) into the NotI-XhoI sites of the vector, and an 850-bp EcoRI-DraI 3' CRH flanking sequence beginning in the $3^{\prime}$ untranslated region (first cloned into pBluescript) into the $\mathrm{XbaI}-\mathrm{KpnI}$ sites of the vector. This construct entirely replaces the preproCRH coding sequences with the neo gene. $25 \mu \mathrm{g}$ of this construct was electroporated into $2 \times 10^{7} \mathrm{ES}$ cells. Selection was performed with G418 (neomycin, $300 \mu \mathrm{g} / \mathrm{ml}$; GIBCO BRL) and gancyclovir ( $2 \mu \mathrm{M}$; Syntex, Palo Alto, CA), and DNA from doubly resistant colonies was isolated and screened by Southern blot after digestion with BamHI and SacI, using as probes either a CRH genomic fragment flanking the $3^{\prime}$ end of the mouse CRH gene outside of the sequence contained within the targeting vector, or the coding region of the neo gene contained within the targeting vector.

Incorporation of the ES clone with targeted inactivation of the CRH allele into chimeric mice. 10-15 ES cells with a targeted mutation in the CRH locus were injected into C57Bl/6 blastocysts at 3.5 days post coitum as described in Bradley (40). Recipients were pseudopregnant $\mathrm{C} 57 \mathrm{Bl} / 6 \times \mathrm{CBA} \mathrm{F} 1$ mice at 2.5 postcoitum. Chimeric offspring were scored on the basis of the appearance of agouti coat color.

\section{Results}

Cloning the mouse $\mathrm{CRH}$ gene. To isolate the mouse CRH gene, a Balb/c library in lambda EMBL3 SP6/T7 was screened with a ${ }^{32}$ P-labeled 700-bp RsaI fragment from the rat CRH gene. From 240,000 plaques screened, one positive phage was obtained. Restriction enzyme analysis revealed that this clone contained a 16-kb insert, with $\sim 12 \mathrm{~kb}$ of DNA sequences $5^{\prime}$ of the CRH gene and $2.5 \mathrm{~kb}$ of $3^{\prime}$ flanking sequence. The entire CRH gene was sequenced, including 446 bp of 5' flank and 300 bp of 3' flank. The regions sequenced confirmed the previously published sequence of Seasholtz et al. (41) of the mouse CRH gene, and extend available promoter sequences an additional 110 bp upstream of the transcription initiation site (Fig. 1). 


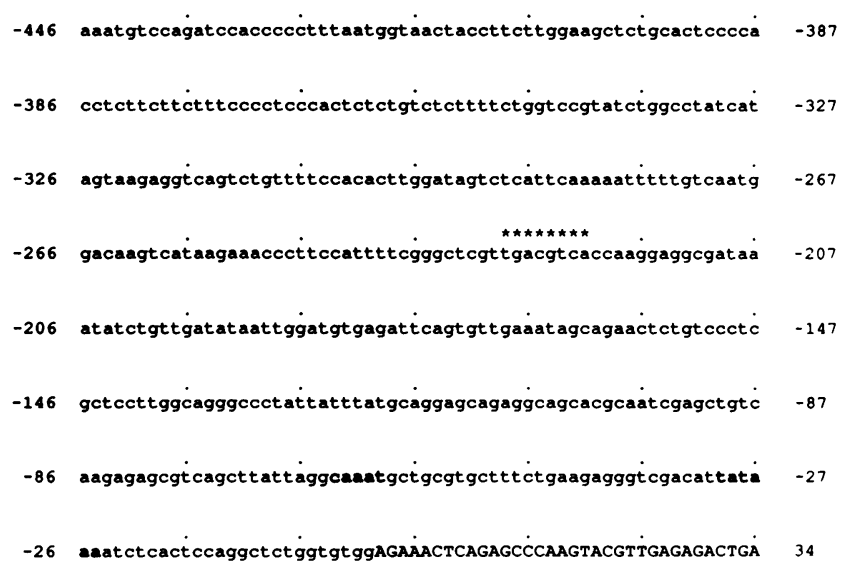

Figure 1. Nucleotide sequence of the 5 ' flanking region of the mouse CRH gene. The nucleotide positions are relative to the site of transcription initiation $(+1)$. Nucleotides in exon 1 are shown in capital letters; the CAAT and TATAA boxes are displayed in bold letters. A consensus cyclic AMP response element is indicated by asterisks.

Additional confirmation that gross rearrangements had not occurred in our genomic clone was obtained by performing a Southern blot comparing cloned and mouse genomic DNA cut with EcoRI, EcoRI plus SalI, or PstI (Fig. 2). Hybridizing bands from the lambda clone and mouse genome were identical.

Chromosomal localization of the mouse CRH gene. The chromosomal location of mouse $\mathrm{CRH}$ was determined by interspecific backcross analysis using progeny derived from matings of $\left[(\mathrm{C} 57 \mathrm{BL} / 6 \mathrm{~J} \times M\right.$. spretus $\left.) \mathrm{F}_{1} \times \mathrm{C} 57 \mathrm{BL} / 6 \mathrm{~J}\right]$ mice. The mapping results indicated that the $\mathrm{CRH}$ locus $(\mathrm{Crh})$ is located in the proximal region of mouse chromosome 3 linked to $\mathrm{Il}-\mathrm{T}$, Glut-2, and $F g f b$. Although 133 mice were analyzed for every marker and are shown in the segregation analysis (Fig. 3), up to 178 mice were typed for some pairs of markers. Each locus was analyzed in pairwise combinations for recombination frequencies using the additional data. The ratios of the total number of mice exhibiting recombinant chromosomes to the total number of mice analyzed for each pair of loci and the most likely gene order are: centromere-Il-7-2/143-Crh-9/143Glut-2-10/178-Fgfb. The recombination frequencies (expressed as genetic distances in centiMorgans $(\mathrm{cM}) \pm$ the stan-

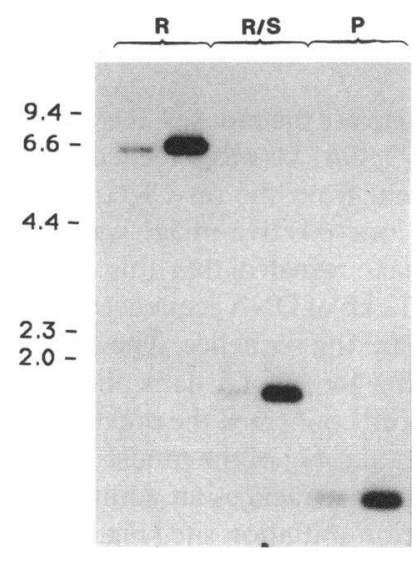

Figure 2. Southern blot analysis of genomic and cloned mouse CRH DNA. Mouse genomic (lighter lane of each pair of di-

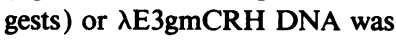
digested with either EcoRI $(R)$, EcoRI and SalI $(R / S)$, or PstI $(P)$. The digested samples were subjected to agarose gel electrophoresis, and transferred to nitrocellulose membranes. The immobilized DNA was hybridized to a labeled fragment from $\lambda E 3 g m C R H$. The positions of fragments generated from HindIII-digested lambda DNA are along the left, with fragment size in kilobase pairs.
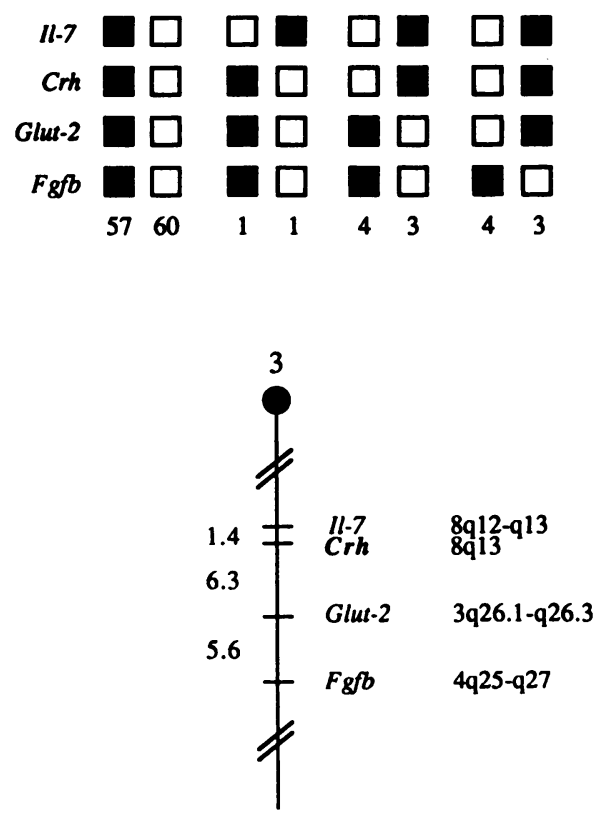

Figure 3. The CRH gene locus ( $\mathrm{Crh}$ ) maps in the proximal region of mouse chromosome 3. Crh was localized to mouse chromosome 3 by interspecific backcross analysis. The segregation patterns of $\mathrm{Crh}$ and flanking genes in 133 backcross animals that were typed for all loci are shown at the top of the figure. For individual pairs of loci, $>133$ animal were typed (see text). Each column represents the chromosome identified in the backcross progeny that was inherited from the $(\mathrm{C} 57 \mathrm{BL} / 6 \mathrm{~J} \times M$. spretus $) \mathrm{F}_{1}$ parent. The shaded boxes represent the presence of a $\mathrm{C} 57 \mathrm{BL} / 6 \mathrm{~J}$ allele and white boxes represent the presence of a $M$. spretus allele. The number of offspring inheriting each type of chromosome is listed at the bottom of each column. A partial chromosome 3 linkage map showing the location of $\mathrm{Crh}$ in relation to linked genes is shown at the bottom of the figure. Recombination distances between loci in centimorgans are shown to the left of the chromosome and the positions of loci in human chromosomes are shown to the right. References for the human map positions of loci mapped in this study can be obtained from GDB (Genome Data Base), a computerized database of human linkage information maintained by The William H. Welch Medical Library of The Johns Hopkins University (Baltimore, MD).

dard error) are: $I l-7-1.4 \pm 1.0-C r h-6.3 \pm 2.0-$ Glut-2-5.6 $\pm 1.7-$ $F g f b$.

We have compared our interspecific map of chromosome 3 with a composite mouse linkage map that reports the map location of many uncloned mouse mutations (compiled by $\mathrm{M}$. T. Davisson, T. H. Roderick, A. L. Hillyard, and D. P. Doolittle, and provided from GBASE, a computerized database maintained at The Jackson Laboratory, Bar Harbor, ME). CRH mapped in a region of the composite map that lacks mouse mutations with a phenotype that might be expected for an alteration in the CRH locus (data not shown).

Tissue distribution of CRH mRNA synthesis. The sites of CRH gene expression in the mouse were determined by a sensitive reverse transcription-PCR method specific for CRH mRNA (Fig. 4). As expected, bands of the size predicted to have arisen from CRH mRNA were seen on the ethidium staining of the agarose gel for cerebral cortex and hypothalamus. After hybridization to labeled CRH sequences, additional positive signals were obtained from the anterior pituitary, adrenal gland, testis, ovary, gut, heart, and lung after 25 cycles of 


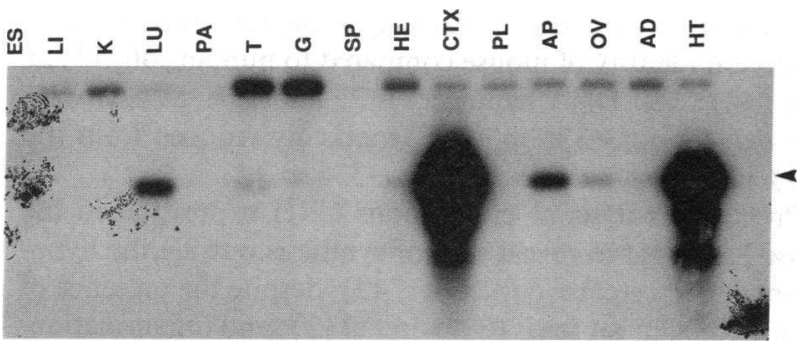

Figure 4. Reverse Transcription-PCR mouse tissue survey for CRH mRNA. $2 \mu \mathrm{g}$ of total RNA was amplified, subjected to agarose gel electrophoresis, transferred to nitrocellulose membranes, then hybridized to a mouse CRH coding region probe. The 585-bp product expected for amplified CRH mRNA is indicated by the arrow, while the top band represents amplification of contaminating mouse genomic DNA. Samples showing the expected CRH mRNA amplification product included lung $(L U)$, testis $(T)$, gut $(G)$, heart $(H E)$, cerebral cortex $(C T X)$, anterior pituitary $(A P)$, ovary $(O V)$, adrenal $(A D)$, and hypothalamus $(H T)$ after 25 cycles of amplification. Embryonic stem cells $(E S)$, liver $(L I)$, kidney $(K)$, pancreas $(P)$, spleen $(S P)$, and placenta $(P L)$ were negative after 25 cycles of PCR, but spleen was positive after 35 cycles of amplification (see Figure 5 ).

amplification. Liver, kidney, pancreas, spleen, and placenta were negative for CRH mRNA after 25 cycles of PCR. Spleen exhibited a positive signal after 35 cycles of PCR (Fig. 5), while kidney remained negative (data not shown).

Because CRH has been implicated as an immunomodulatory factor, we sought to determine the cell type of origin of $\mathrm{CRH}$ within the immune system more precisely. Mouse splenocytes were separated into macrophage (adherent) and lymphocyte (non-adherent) components by plating onto tissue culture dishes. The non-adherent fraction was further separated into B-lymphocytes and T-lymphocytes by fluorescence-activated cell sorting (36) using the B-cell specific surface marker CD45 and T-cell specific marker Thy 1.2. The B- and T-cell components were each $>98 \%$ pure after FACS (Fig. 5, $a$ and $b$ ). Total RNA from macrophages, T-cells, and B-cells was processed separately and subjected to reverse transcription-PCR. CRH mRNA was detected in T-cells, but not B-cells or macrophages, after 35 cycles of PCR (Fig. $5 c$ ). We confirmed the integrity of the macrophage RNA by successful amplification of interleukin- $1 \alpha$ cDNA, indicating the absence of CRH mRNA in this pool was not due to sample degradation (data not shown).

Inactivation of the CRH gene in ES cells and generation of mice chimeric for the mutant $C R H$ allele. We used our mouse $\mathrm{CRH}$ genomic clone with the vector pPNT to generate a construct for homologous recombination (Fig. 6). After electroporation of this construct into $6 \times 10^{7} \mathrm{ES}$ cells and selection with G418 and gancyclovir, doubly resistant cell lines were isolated and analyzed by Southern blot for inactivation of the $\mathrm{CRH}$ gene. After restriction digestion of ES DNA with BamHI and SacI, and hybridization to a genomic DNA fragment from the CRH 3' flanking region distal to sequences contained within the targeting vector, a band of $3.7 \mathrm{~kb}$ is expected for the normal allele, and a band of $2.7 \mathrm{~kb}$ should also be present in cases where appropriate targeting had occurred (Fig. 6). Two out of 127 doubly resistant clones screened were found to have undergone homologous recombination (Fig. 7). By Southern blot, these two lines (1B6 and 3D1) had a normal 3.7-kb CRH allele $50 \%$ as intense as in unmanipulated ES cells, and an equally intense $2.7-\mathrm{kb}$ band representing the mutant $\mathrm{CRH}$ allele. Additional Southern blot analysis with a neo probe, and digestion with enzymes to verify appropriate recombination at the $5^{\prime}$ end of the vector showed that in the targeted clones there were not additional random integration events, or tandem integrants at the CRH locus (data not shown).

Blastocysts injected with both targeted ES clones gave rise to chimeric mice. $50 \%$ of blastocysts injected with line 3D1 gave rise to viable offspring, and $50 \%$ of these offspring were chimeric for coat color, with chimerism ranging between 20 and $95 \%$. All offspring, including those most highly chimeric, have had normal growth rates and appear healthy.

\section{Discussion}

We have cloned the mouse CRH gene and determined its nucleotide sequence as well as its pattern of expression in vivo.
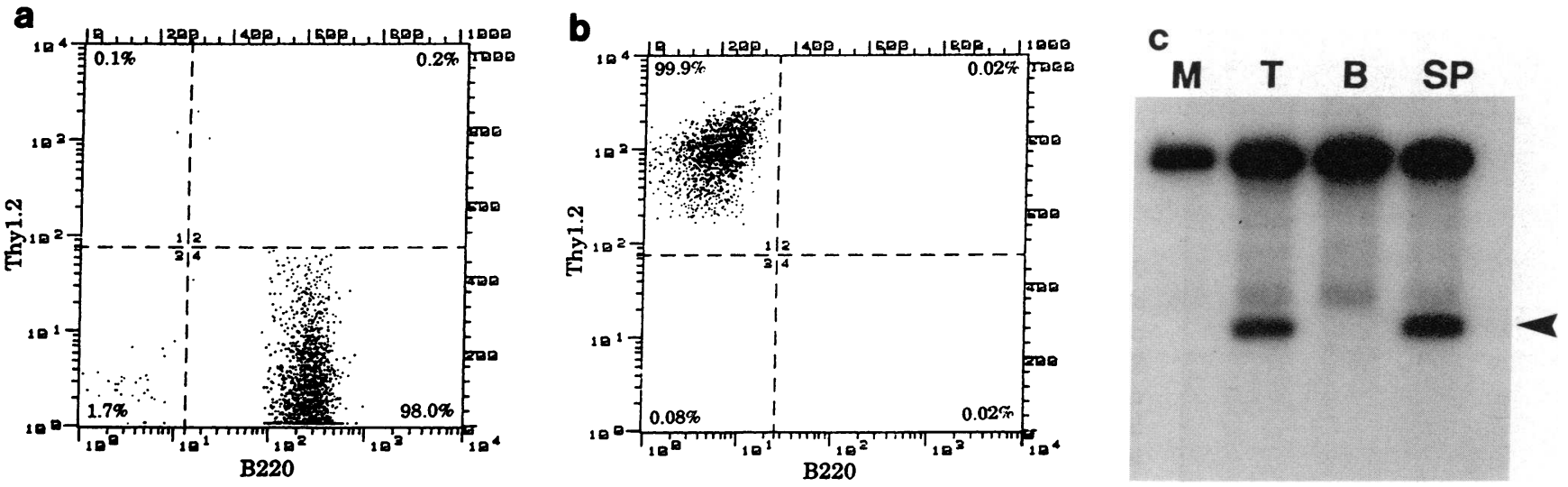

Figure 5. Mouse T-lymphocytes synthesize CRH mRNA. Splenocytes were separated into monocyte- and lymphocyte-enriched populations by adherence to tissue culture dishes. The non-adherent population (lymphocytes) was incubated with fluorescein isothiocyanate-conjugated monoclonal anti-mouse CD45 and phycoerythrin-conjugated monoclonal anti-mouse Thy 1.2 antibodies and subjected to FACS. After the initial flow sorting, an aliquot of the B-cell- and T-cell-enriched pools were subjected to flow cytometry to determine the purity of the samples. $(a)$ Flow cytometry of B-cell-enriched pool. $(b)$ Flow cytometry T-cell-enriched pool. Actual percentage of cells is indicated in each quadrant. $(c)$ Total RNA was prepared from monocyte $(M)$, T-cell $(T)$, B-cell $(B)$, and unfractionated spleen $(S P)$, then subjected to reverse transcription PCR, using 35 cycles of amplification. The 585-bp product represents amplification of CRH mRNA (arrowhead). 


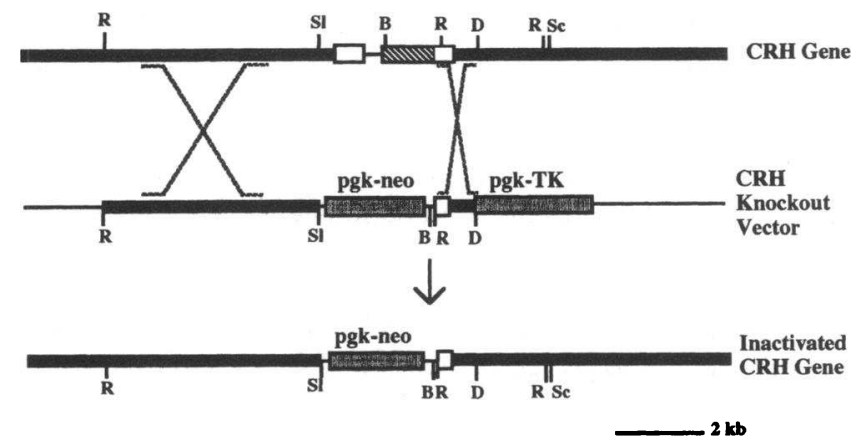

Figure 6. Strategy to inactivate the CRH gene by homologous recombination. To create the CRH knockout vector, a 5-kb EcoRI-SalI 5 ' flanking region fragment and an 850-bp EcoRI-DraI 3' flanking fragment of the mouse CRH gene were inserted into the plasmid pPNT. After electroporation into D3 ES cells, successful homologous recombination (as depicted by the stippled lines) should occur between the endogenous CRH gene and the CRH knockout vector to create an inactivated CRH gene. (Thick black line) CRH gene flanking regions; (open boxes) $\mathrm{CRH}$ noncoding exons; (hatched box) preproCRH coding region; ( stippled boxes) pgk-neo and pgk-TK genes. Restriction sites: $R$, EcoRI; $S 1$, SalI; $B$, BamHI; $D$, DraI; and $S c$, SacI.

CRH expression in humans has been implicated in inflammation (42) and pathologic states such as depression (43), anorexia nervosa (44), and obesity (45). A molecular genetic analysis of the role of CRH in the regulation of the HPA axis in both normal and pathologic states requires the construction of suitable animal models in which CRH gene structure and function can be manipulated. Currently, the mouse provides the most powerful mammalian system for introducing defined genetic mutations, such as gene "knockouts" via homologous recombination in embryonic stem cells, or chimeric transgenes where putative tissue-specific regulatory regions drive expression of an indicator gene.

To this end, we have isolated and characterized the mouse gene. Our results are in agreement with the previously published nucleotide sequence data of Seasholtz et al. (41), with

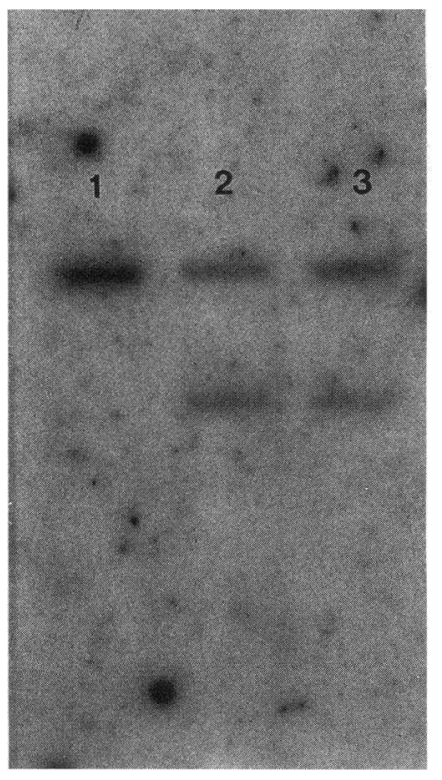

Figure 7. Identification of ES clones with targeted mutation of the CRH locus. Genomic Southern blot of DNA from control (1), line 1B6 (2), and line 3D1 (3) cells. The probe is from the $3^{\prime}$ flanking region of the CRH locus, outside the region containing the targeting vector. DNA was digested with BamHI and Sacl; the upper 3.7-kb band represents the normal CRH allele while the lower band is the targeted 2.7$\mathrm{kb}$ product. the addition of extended $5^{\prime}$ flanking sequences. Interestingly, the percent identity of mouse compared to human $(46,47)$ or ovine (48) CRH DNA sequences is 75 and $72 \%$, respectively, from nucleotides -336 to -446 , markedly reduced from the $>90 \%$ identity of sequences from -336 to +1 .

Previous analysis of endogenous CRH expression in the mouse has failed to reveal sites of synthesis outside the hypothalamus and cerebral cortex $(41,49)$, despite the presence of CRH mRNA in rat testis (3), adrenal (3), and inflammationstimulated spleen (11), as well as the finding of lung (8) and ovarian (6) CRH peptide expression by radioimmunoassay in humans and rats. We have developed a highly sensitive reverse transcription-PCR method specific for CRH mRNA, and have demonstrated many sites of CRH expression outside of the brain, including in lung, adrenal, pituitary, testis, ovary, heart, and spleen. Interestingly, mice transgenic for the metallothionein promoter driving expression of the $\mathrm{CRH}$ structural gene showed CRH transgene expression in appropriate brain sites as well as in lung, adrenal, heart, and testis (49). This suggests that DNA elements within the CRH structural gene may be important in directing tissue-specific expression. The functional significance of $\mathrm{CRH}$ production at these sites is currently unknown, but can be addressed using classical methods such as mRNA in situ hybridization or immunohistochemical analysis to determine cell type of origin, and analysis of changes in expression during ontogeny or in response to exogenous stimuli. Alternatively, the phenotype imparted to mice with null mutations at the $\mathrm{CRH}$ locus may be highly informative in this regard.

CRH peptide and its receptor (50) have been found in the immune system where they have been suggested to have both stimulatory $(11,16)$ and suppressive $(15,51)$ roles. CRH has been shown to be a mitogen for lymphocytes in vitro (52), as well as accentuating the response to other mitogens (53). At peripheral inflammatory sites, CRH may act in an autocrine or paracrine fashion to modulate the immune response (16). We have found CRH expression in the spleen of nonstimulated mice. Upon fractionation of splenocytes, we have localized CRH mRNA expression to T-cells and have shown it is not expressed in splenic B-cells or macrophages. Ekman et al. (12) have noted CRH mRNA expression in human T-cells after stimulation with phorbol ester and phytohemagglutinin in vitro, but not in the nonstimulated state using a less sensitive and specific RNA dot blot hybridization method, with which they surprisingly also detected CRH mRNA in liver, a site not found to have CRH mRNA by techniques of similar sensitivity by several other investigators $(3,41,49)$, but not in brain. Other groups have found CRH in leukocytes as well, without definitive elucidation of the cell type of origin $(10,54)$. The finding of CRH in T-cells highlights the similarity in intercellular communication pathways between the neuroendocrine and immune systems $(55,56)$, since B-cells have been found to produce proopiomelanocortin and its cleavage product, betaendorphin (57). Our findings also provide an additional pathway through which the neuroendocrine and immune systems may communicate to modulate the other's responses.

To determine if naturally occurring mutations of CRH gene in mice were available for characterization of the phenotype imparted by CRH-deficiency, the chromosomal location of the mouse CRH gene was determined. Using interspecific backcross analysis, we mapped CRH to chromosome 3, between $\mathrm{Il-7}$ and Glut-2. These data are in agreement with two 
very recently published reports showing linkage to CRH with the carbonic anhydrase II gene $(58,59)$, also on mouse chromosome 3. The distance between the $\mathrm{Crh}$ locus and flanking markers is much closer in our study ( $1.4 \mathrm{cM}$ to $\mathrm{Il}-7)$ than in the prior two studies ( $5.4 \mathrm{cM}$ to carbonic anhydrase II (58), 11.3 cM to interleukin-2) (59). The close linkage of CRH and Il-7 in the mouse and the mapping of these two genes to human chromosome 8 (8q12-q13) (60) is consistent with the known linkage homologies that exist between mouse and humans. These data extend the region of human chromosome 8 homology on mouse chromosome 3 another $1.4 \mathrm{cM}$ distal to $\mathrm{Il}-7$. Unfortunately, no mutations in this area of mouse chromosome 3 have been reported which are suggestive of $\mathrm{CRH}$ deficiency. For this reason, we inactivated the CRH gene in ES cells and have created chimeric mice using this mutant ES cell line. We have recently bred to homozygosity mice heterozygous for CRH deficiency. Despite a complete lack of CRH, these mice are viable (L. Muglia and J. Majzoub, unpublished observations). Knowledge of the sites of mouse CRH expression together with a mouse model of $\mathrm{CRH}$ deficiency should facilitate understanding of the role of $\mathrm{CRH}$ in endocrine, immune and other functions.

\section{Acknowledgements}

We thank members of the Majzoub laboratory for helpful discussions, Brian Cho for excellent technical assistance, and R. Mulligan and R. Hynes for reagents.

This work was supported by grants from the Markey Charitable Trust (L. J. Muglia), Child Health Research Center at Children's Hospital (L. J. Muglia), Pfizer Pharmaceuticals (L. J. Muglia), the National Institutes of Health (J. A. Majzoub), and the National Cancer Institute, Department of Health and Human Services, under contract NO1-CO-74101 with Advanced BioScience Laboratories, Inc.

\section{References}

1. Vale, W., C. Rivier, M. R. Brown, J. Spiess, G. Koob, L. Swanson, L. Bilezikjian, F. Bloom, and J. Rivier. 1983. Chemical and biological characterization of corticotropin releasing factor. Rec. Prog. Horm. Res. 39:245-270.

2. Grigoriadis, D., J. Jeroux, and E. De Souza. 1993. Characterization and regulation of corticotropin-releasing factor receptors in the central nervous, endocrine, and immune systems. In Corticotropin Releasing Factor. W. Vale, editor. John Wiley and Sons, Chichester, England. 85-100.

3. Thompson, R. C., A. F. Seasholtz, and E. Herbert. 1987. Rat corticotropin releasing hormone gene: sequence and tissue-specific expression. Mol. Endocrinol. 1:363-370.

4. Fabbri, A., J. Tinagero, and M. Dufau. 1990. Corticotropin-releasing factor is produced by rat Leydig cells and has a major local antireproductive effect in the testis. Endocrinology. 127:1541-1543.

5. Yoon, J., C. Sklar, and R. David. 1988. Presence of immunoreactive corticotropin releasing factor in rat testis. Endocrinology. 122:759-761.

6. Mastorakos, G., E. L. Webster, T. C. Friedman, and G. Chrousos. 1993. Immunoreactive corticotropin-releasing hormone and its binding sites in the rat ovary. J. Clin. Invest. 92:961-968.

7. Bruhn, T., W. England, E. Anthony, D. Gann, and I. Jackson. 1987. Corticotropin releasing factor in adrenal medulla. Ann. NY Acad. Sci. 512:115-128.

8. Suda, T., N. Tomori, F. Tozawa, T. Mouri, H. Demara, and K. Shizume. 1984. Distribution and characterization of immunoreactive corticotropin releasing factor in human tissues. J. Clin. Endocrinol. \& Metab. 59:861-866.

9. Grino, M., G. Chrousos, and A. N. Margioris. 1987. The corticotropin releasing hormone gene is expressed in human placenta. Biochem. Biophys. Res. Commun. 148:1208-1214.

10. Aird, F., C. V. Clevenger, M. B. Prystowsky, and E. Redei. 1993. Corticotropin-releasing factor mRNA in rat thymus and spleen. Proc. Natl. Acad. Sci. USA. 90:7104-7108.

11. Crofford, L., H. Sano, K. Karalis, E. Webster, E. Goldmuntz, G. Chrousos, and R. Wilder. 1992. Local secretion of corticotropin releasing hormone in the joints of Lewis rats with inflammatory arthritis. J. Clin. Invest. 90:25552564.
12. Ekman, R. B. Servenius, M. G. Castro, P. J. Lowry, A.-S. Cederlund, O. Bergman, and H. O. Sjogren. 1993. Biosynthesis of corticotropin-releasing hormone in human T-lymphocytes. J. Neuroimmunol. 44:7-14.

13. Thind, K., and P. Goldsmith. 1989. Corticotropin releasing factor neurons innervate dopamine neurons in the periventricular hypothalamus of juvenile macaques. Synaptic evidence for a possible companion neurotransmitter. Neuroendocrinol. 50:351-358.

14. Koob, G., S. Heinrichs, E. Pich, F. Menzaghi, H. Baldwin, K. Miczek, and K. Britton. 1993. The role of corticotropin releasing factor in behavioural responses to stress. In Corticotropin Releasing Factor. John Wiley and Sons, Chichester, England. 277-289.

15. Hagan, P., S. Poole, and A. F. Bristow. 1992. Immunosuppressive activity of corticotrophin-releasing factor: inhibition of interleukin-1 and interleukin-6 production by human mononuclear cells. Biochem. J. 281:251-254.

16. Karalis, K., H. Sano, J. Redwine, S. Listwak, R. Wilder, and G. Chrousos. 1991. Autocrine or paracrine inflammatory actions of corticotropin-releasing hormone in vivo. Science (Wash., DC). 254:421-423.

17. Vale, W., J. Spiess, C. Rivier, and J. Rivier. 1981. Characterization of a 41-residue ovine hypothalamic peptide that stimulates secretion of corticotropin and beta-endorphin. Science (Wash. DC). 213:1394-1397.

18. Cole, B., M. Cado, L. Stinus, J. Rivier, and W. Vale. 1990. Central administration of a CRF antagonist blocks the development of stress induced behavioral sensitization. Brain Res. 512:343-346.

19. Suda, T., Y. Nakano, F. Tozawa, T. Sumitomo, Y. Sato, M. Yamada, and H. Demura. 1992. The role of corticotropin-releasing factor and vasopressin in hypoglycemia induced proopiomelanocortin gene expression in the rat anterior pituitary gland. Brain Res. 579:303-308.

20. Smoak, B., P. Deuster, D. Rabin, and G. Chrousos. 1991. Corticotropinreleasing hormone is not the sole factor mediating exercise-induced adrenocorticotropin release in humans. J. Clin. Endocrinol. \& Metab. 73:302-306.

21. Adler, G. K., and J. A. Majzoub. 1987. Influence of infused hypertonic saline on the response to insulin-induced hypoglycemia in man. J. Clin. Endocrinol. \& Metab. 65:116-121.

22. Tomori, N., T. Suda, Y. Nakagami, F. Tozawa, T. Sumitomo, T. Ushiyama, H. Demura, and K. Shizume. 1989. Adrenergic modulation of adrenocorticotropin responses to insulin-induced hypoglycemia and corticotropin-releasing hormone. J. Clin. Endocrinol. \& Metab. 68:87-93.

23. Mansour, S., K. Thomas, and M. Cappechi. 1988. Disruption of the proto-oncogene int- 2 in mouse embryo derived stem cells: a general strategy for targeting mutations to non-selectable genes. Nature (Lond.). 336:348-352.

24. Frim, D. M., B. G. Robinson, K. B. Pasieka, and J. A. Majzoub. 1990. Differential regulation of corticotropin-releasing hormone mRNA in rat brain. Am. J. Physiol. 258 (Endocrinol. Metab. 21):E686-E692.

25. Sambrook, J., E. F. Fritsch, and T. Maniatis. 1989. Molecular Cloning: A Laboratory Manual. Second edition. Cold Spring Harbor Laboratory Press, Cold Spring Harbor, NY.

26. Sanger, F., S. Nicklen, and A. R. Coulson. 1977. DNA sequencing with chain-terminating inhibitors. Proc. Natl. Acad. Sci. USA. 74:5463-5467.

27. Frim, D. F., R. L. Emanuel, B. G. Robinson, C. M. Smas, G. K. Adler, and J. A. Majzoub. 1988. Characterization and gestational regulation of preprocorticotropin releasing hormone messenger RNA in the human placenta. J. Clin. Invest. 82:287-292.

28. Copeland, N. G., and N. A. Jenkins. 1991. Development and applications of a molecular linkage map of the mouse genome. Trends Genet. 7:113-118.

29. Jenkins, N. A., N. G. Copeland, B. A. Taylor, and B. K. Lee. 1982. Organization, distribution, and stability of endogenous ectopic murine leukemia virus DNA sequences in chromosomes of Mus musculus. J. Virol. 43:26-36.

30. Siracusa, L. D., M. H. Rosner, M. A. Vigano, D. J. Gilbert, L. M. Staudt, N. G. Copeland, and N. A. Jenkins. 1991. Chromosomal location of the octamer transcription factors, $O t f-1, O t f-2$, and $O t f-3$, defines multiple $O t f-3$-related sequences dispersed in the mouse genome. Genomics. 10:313-326.

31. Hogan, A., S. Heyner, M. J. Charron, N. G. Copeland, D. J. Gilbert, N. A. Jenkins, B. Thorens, and G. A. Schultz. 1991. Glucose transporter gene expression in early mouse embryos. Development (Camb.). 113:363-372.

32. Cox, R. D., N. G. Copeland, N. A. Jenkins, and H. Lehrach. 1991. Interspersed repetitive element polymerase chain reaction product mapping using a mouse interspecific backcross. Genomics. 10:375-384.

33. Green, E. L. 1981. Linkage, recombination, and mapping. In Genetics and Probability in Animal Breeding Experiments. Oxford University Press, New York. 77-113.

34. Chirgwin, J. M., A. E. Przybyla, R. J. MacDonald, and W. J. Rutter. 1979. Isolation of biologically active ribonucleic acid from sources enriched in ribonuclease. Biochemistry. 18:5294-5299.

35. Murray, L. J., R. Lee, and C. Martens. 1990 . In vivo cytokine gene expression in T cell subsets of the autoimmune MRL/Mp-lpr/lpr mouse. Eur. J. Immunol. 20:163-170.

36. Parks, D. R., L. A. Herzenberg, and L. A. Herzenberg. 1989. Flow cytometry and Fluorescence-activated cell sorting. In Fundamental Immunology, Second Edition. W. E. Paul, editor. Raven Press Ltd., New York. 781-802.

37. Doetschman, T. C., H. Eistetter, M. Katz, W. Schmidt, and R. Kemler. 
1985. The in vitro development of blastocyst-derived embryonic stem cell lines: formation of visceral yolk sac, blood islands and myocardium. J. Embryol. Exp. Morphol. 87:27-45.

38. Robertson, E. J. 1987. Embryo-derived stem cell lines. In Teratocarcinomas and embryonic stem cells. A practical approach. IRL Press, Oxford. 71-112.

39. Tybulewicz, V., C. Crawford, P. Jackson, R. Bronson, and R. Mulligan. 1991. Neonatal lethality and lymphopenia in mice with a homozygous disruption of the c-abl proto-oncogene. Cell. 65:1153-1163.

40. Bradley, A. 1987. Production and analysis of chimeric mice. In Teratocarcinomas and Embryonic Stem Cells. A practical approach. E. J. Robertson, editor. IRL Press, Oxford. 113-151.

41. Seasholtz, A. F., F. J. Bourbonais, C. E. Harnden, and S. Camper. 1991. Nucleotide sequence and expression of the mouse corticotropin-releasing hormone gene. Mol. Cell. Neurosci. 2:266-273.

42. Crofford, L. J., H. Sano, K. Karalis, T. C. Friedman, H. R. Epps, E. F Remmers, P. Mathern, and G. P. Chrousos. 1993. Corticotropin-releasing hormone in synovial fluids and tissues of patients with rheumatoid arthritis and osteoarthritis. J. Immunol. 151:1587-1596.

43. Gold, P. W., D. L. Loriaux, A. Roy, M. A. Kling, J. R. Calabrese, C. J. Kellner, L. K. Nieman, R. M. Post, D. Pickar, W. Galluci, P. Avgerinos, S. Paul, E. H. Oldfield, G. B. Cutler, Jr., and G. P. Chrousos. 1986. Responses to corticotropin-releasing hormone in the hypercortisolism of depression and Cushing's Disease. Pathophysiologic and diagnostic implications. N. Engl. J. Med 314:1329-1335.

44. Gold, P. W., H. Gwirtzman, P. Avgerinos, L. K. Nieman, W. T. Galluci W. Kaye, D. Jimerson, M. Ebert, R. Rittmaster, D. L. Loriaux, and G. P. Chrousos. 1986. Abnormal hypothalamic-pituitary-adrenal function in anorexia nervosa. Pathophysiologic mechanisms in underweight and weight corrected patients. N. Engl. J. Med. 314:1335-1342.

45. Morley, J. E. 1987. Neuropeptide regulation of appetite and weight. Endocr. Rev. 8:256-287.

46. Vamvakopoulos, N. C. M. Karl, V. Mayol, T. Gomez, C. A. Stratakis, A. Margioris, and G. P. Chrousos. 1990. Structural analysis of the regulatory region of the human corticotropin releasing hormone gene. FEBS (Fed. Eur. Biochem. Soc.) Lett. 267:1-5.

47. Shibahara, S., Y. Morimoto, M. Furutani, H. Notake, H. Takahashi, S Shimizu, S. Horikawa, and S. Numa. 1983. Isolation and sequence analysis of the human corticotropin-releasing factor precursor gene. EMBO (Eur. Mol. Biol. Organ.) J. 2:775-779.
48. Roche, P. J., R. J. Crawford, R. T. Fernley, G. W. Tregear, and J. P. Coghlan. 1988. Nucleotide sequence of the gene coding for ovine corticotropinreleasing factor and regulation of its mRNA levels by glucocorticoids. Gene (Amst.). 71:421-431.

49. Stenzel-Poore, M. P., V. A. Cameron, J. Vaughn, P. E. Sawchenko, and W. Vale. 1992. Development of Cushing's Syndrome in corticotropin-releasing factor transgenic mice. Endocrinology. 130:3378-3386.

50. Webster, E. L., D. E. Tracey, M. A. Jutila, S. A. Wolfe, and E. B. de Souza. 1990. Corticotropin-releasing factor receptors in mouse spleen: identification of receptor bearing cells as resident macrophages. Endocrinology. 127:440-452.

51. Jain, R., D. Zwickler, and C. Hollander. 1991. Corticotropin releasing factor modulates the immune response to stress in the rat. Endocrinology. 128:1329-1336.

52. McGillis, J. P., A. Park, P. Rubin-Fletter, C. Turek, M. F. Dallman, and D. G. Payan. 1989. Stimulation of rat B-lymphocyte proliferation by corticotropin-releasing factor. J. Neurosci. Res. 23:346-352.

53. Singh, V. K. 1989. Stimulatory effects of corticotropin-releasing neurohormone on human lymphocyte proliferation and interleukin-2 receptor expression. J. Neuroimmunol. 23:257-262.

54. Stephanou, A., D. S. Jessop, R. A. Knight, and S. L. Lightman. 1990. Corticotrophin-releasing factor-like immunoreactivity and mRNA in human leukocytes. Brain Behav. Immun. 4:67-73.

55. Bateman, A., A. Singh, T. Kral, and S. Solomon. 1989. The immune-hypothalamic-pituitary-adrenal axis. Endocr. Rev. 10:92-112.

56. Smith, E. M., and J. E. Blalock. 1988. A molecular basis for interactions between the immune and neuroendocrine systems. Int. J. Neurosci. 38:455-464.

57. Kavelaars, A., R. E. Ballieux, and C. J. Heijnen. 1989. The role of IL-1 in the corticotropin-releasing factor and arginine-vasopressin-induced secretion of immunoreactive $\beta$-endorphin by human peripheral blood mononuclear cells. $J$. Immunol. 142:2338-2342.

58. Smoller, J. W., G. E. Truett, J. Hirsch, and R. L. Leibel. 1993. The Zucker fatty ( $f a$ ) gene is not a mutation of corticotropin-releasing factor. Am. J. Physiol. 264 (Regulatory Integrative Comp. Physiol. 33):R12-R15.

59. Knapp, L., C. Keegan, A. Seasholtz, and S. Camper. 1993. Corticotropinreleasing hormone $(\mathrm{Crh})$ maps to mouse Chromosome 3. Mamm. Genome. 4:615-616.

60. Arbiser, J. L., C. C. Morton, G. A. P. Bruns, and J. A. Majzoub. 1988 Human corticotropin-releasing hormone gene is located on the long arm of chromosome 8. Cytogenet. Cell Genet. 47:113-116. 